\author{
Federal Reserve Bank of New York \\ Staff Reports
}

\title{
Supervising Large, Complex Financial Institutions: What Do Supervisors Do?
}

\author{
Thomas Eisenbach \\ Andrew Haughwout \\ Beverly Hirtle \\ Anna Kovner \\ David Lucca \\ Matthew Plosser
}

Staff Report No. 729

May 2015

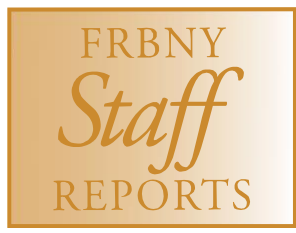

This paper presents preliminary findings and is being distributed to economists and other interested readers solely to stimulate discussion and elicit comments. The views expressed in this paper are those of the authors and do not necessarily reflect the position of the Federal Reserve Bank of New York or the Federal Reserve System. Any errors or omissions are the responsibility of the authors. 


\title{
Supervising Large, Complex Financial Institutions: What Do Supervisors Do?
}

Thomas Eisenbach, Andrew Haughwout, Beverly Hirtle, Anna Kovner, David Lucca, and Matthew Plosser

Federal Reserve Bank of New York Staff Reports, no. 729

May 2015

JEL classification: G21, G28

\begin{abstract}
The Federal Reserve is responsible for the prudential supervision of bank holding companies (BHCs) on a consolidated basis. Prudential supervision involves monitoring and oversight to assess whether these firms are engaged in unsafe or unsound practices, as well as ensuring that firms are taking corrective actions to address such practices. Prudential supervision is interlinked with, but distinct from, regulation, which involves the development and promulgation of the rules under which BHCs and other regulated financial intermediaries operate. This paper describes the Federal Reserve's supervisory approach for large, complex financial companies and how prudential supervisory activities are structured, staffed, and implemented on a day-to-day basis at the Federal Reserve Bank of New York as part of the broader supervisory program of the Federal Reserve System. The goal of the paper is to generate insight for those not involved in supervision into what supervisors do and how they do it. Understanding how prudential supervision works is a critical precursor to determining how to measure its impact and effectiveness.
\end{abstract}

Key words: bank supervision, large and complex financial companies

Eisenbach, Haughwout, Hirtle, Kovner, Lucca, Plosser: Federal Reserve Bank of New York. Corresponding authors: Beverly Hirtle and David Lucca (e-mails: beverly.hirtle@ny.frb.org, david.lucca@ny.frb.org). The authors thank Nicola Cetorelli, Tim Clark, Sarah Dahlgren, Dianne Dobbeck, Michael Gibson, Jack Gutt, James Mahoney, Steven Manzari, and Jamie McAndrews for comments and suggestions on earlier drafts of this paper, and colleagues in the Financial Institution Supervision Group and the Legal Group at the Federal Reserve Bank of New York for extensive input and background information. The views expressed in this paper are those of the authors and do not necessarily reflect the position of the Federal Reserve Bank of New York or the Federal Reserve System. 


\section{Table of Contents}

I. Overview and Background ..............................................................................................1

II. Goals and Structure of Supervision ...........................................................................

II.A Authority, Goals and Strategy …………………...................................................... 3

II.B Structure: Institutions and Portfolios .............................................................................. 6

III. Organization: How is FRBNY Supervisory Staff Organized? .....................10

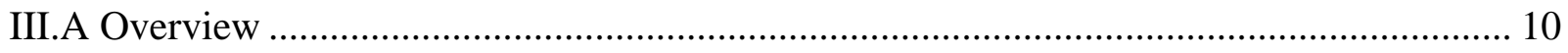

III.B Firm-Focused Supervisory Teams............................................................................ 11

III.C Risk Department Specialists ................................................................................... 13

III.D Large Foreign Banks ............................................................................................ 15

III. E Coordination and Information-Sharing within FISG .................................................... 16

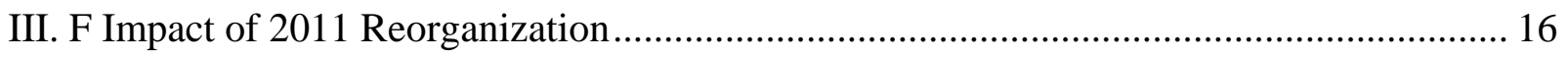

III. G Interaction with Other Supervisors............................................................................. 20

IV. Work Content: What Do Supervisors Do? ......................................................21

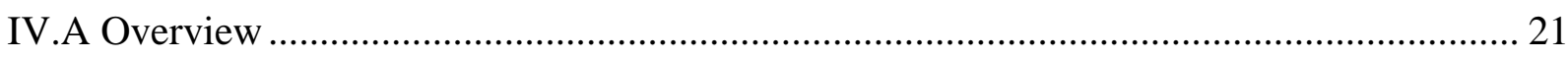

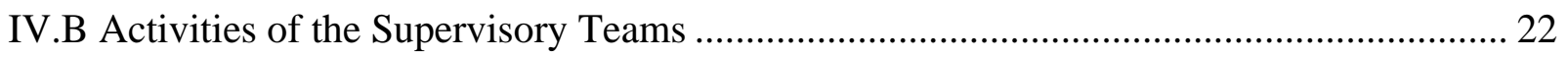

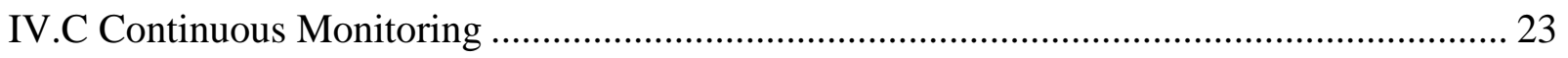

IV.D Enhanced Continuous Monitoring and Examinations...................................................... 26

IV.E Remedial Steps and Follow-up .............................................................................. 28

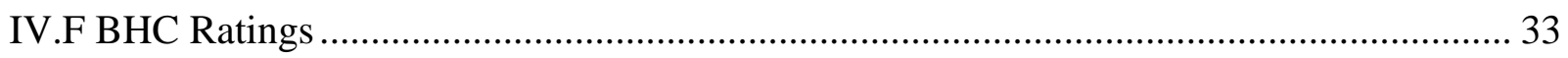

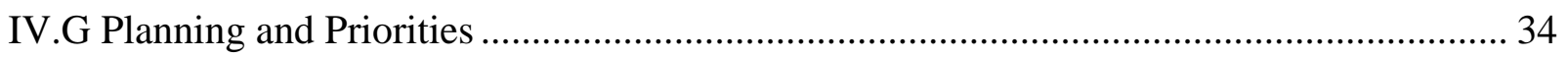

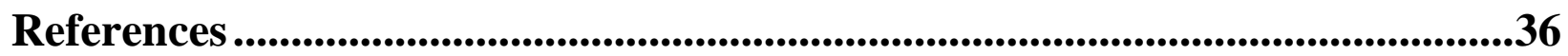


"An Act To provide for the establishment of Federal reserve banks, to furnish an elastic currency, to afford means of rediscounting commercial paper, to establish a more effective supervision of banking in the United States, and for other purposes."

- Federal Reserve Act, Official Title

\section{Overview and Background}

The Federal Reserve is responsible for the prudential supervision of bank holding companies (BHCs) on a consolidated basis, as well as of certain other financial institutions operating in the United States. Prudential supervision involves monitoring and oversight of these firms to assess whether they are in compliance with law and regulation and whether they are engaged in unsafe or unsound practices, as well as ensuring that firms are taking corrective actions to address such practices. Prudential supervision is inter-linked with, but distinct from, regulation of these firms, which involves the development and promulgation of the rules under which BHCs and other regulated financial intermediaries operate. The distinction between supervision and regulation is sometimes blurred in the discussion by academics, researchers and analysts who write about the banking industry, and the terms "supervision" and "regulation" are often used somewhat interchangeably. ${ }^{2}$ Moreover, while prudential supervision is a central responsibility of the Federal Reserve and consequently accounts for substantial resources, the responsibilities, powers and day-to-day activities of Federal Reserve supervision staff are often not very transparent to those outside of the supervision areas of the Federal Reserve System (“System”).

This paper aims to help fill this knowledge gap by describing how prudential supervisory activities are structured, staffed and implemented on a day-to-day basis at the Federal Reserve Bank of New York (FRBNY). The primary focus of this discussion is on the supervision of large, complex bank holding companies and of the largest foreign banking organizations (FBOs) and non-bank financial companies designated by the Financial Stability Oversight Council

\footnotetext{
${ }^{2}$ See Mishkin (2001) and Masciandaro and Quintyn (2013) for surveys of the academic literature on supervision and regulation. See Board of Governors of the Federal Reserve System (2005) for a fuller discussion of the distinction between supervision and regulation.
} 
(FSOC) for supervision by the Federal Reserve. The paper focuses on oversight of these firms because they are the most systemically important banking and financial companies and thus prudential supervision of them is especially consequential. Given their size and complexity, the approach to supervision of these companies also differs from that taken for smaller and less complex firms. It is important to note that supervision of these large, complex firms is conducted through a comprehensive System-wide program governing supervisory policies, activities and outcomes. ${ }^{3}$ The discussion in this paper focuses solely on supervisory staff located at the Federal Reserve Bank of New York, whose activities are carried out as part of this broader program. ${ }^{4}$

The paper is based on information from three main sources. First, in the spring and summer of 2014, we had a series of discussions staff of the FRBNY Financial Institution Supervision Group (FISG) involved in the day-to-day supervision of the large, complex banking and financial institutions. In addition to these discussions, we also relied on various written materials describing the structure and goals of supervision at FRBNY and in the Federal Reserve System, selected guidelines provided to supervisory staff, and Federal Reserve Supervisory and Regulation Letters (SR Letters) describing expectations and objectives of the Federal Reserve's supervisory program for large, complex banking companies. Finally, we pair the descriptive analysis with FISG management data about supervisory inputs-FISG supervisory staff headcounts and hours by departments and activities—and outputs (supervisory actions).

The paper is intended to provide an overview of the way prudential supervision of large, complex bank and nonbank financial institutions is structured and implemented at FRBNY. As such, the goal is to generate insight for those not involved in supervision into what supervisors do and how they do it, rather than to document every element in complete detail or to provide an "end-to-end" description of the supervisory process. Further, while we explain the stated rationale for the approaches taken, we do not assess whether the structure and implementation

\footnotetext{
${ }^{3}$ The structure of this program is described in Supervision Letter 15-7 ("Governance Structure of the Large Institution Supervision Coordinating Committee (LISCC) Supervisory Program”) (Board of Governors of the Federal Reserve System 2015c).

${ }^{4}$ The paper does not cover prudential supervision of financial market utilities, although these institutions are also large, complex and systemically important. However, the activities of these organizations and the supervisory issues they present are sufficiently distinct from those of most BHCs that the paper focus on prudential supervision of the more traditional BHCs and nonbank financial intermediaries.
} 
are efficient or meet specific objectives. Understanding how prudential supervision works is a critical precursor to determining how to measure its impact and effectiveness.

The rest of the paper describes how prudential supervision of large, complex bank and nonbank financial companies is structured and implemented at FRBNY. The next section begins by describing the broad goals of prudential supervision and the primary strategies adopted to achieve those goals, as outlined in various Federal Reserve System and FRBNY documents. The section then describes the structure of supervision in the Federal Reserve and provides an overview of the Financial Institution Supervision Group at FRBNY. Section III discusses how the people who do prudential supervision at FRBNY are organized into departments and teams and how the different teams relate to one another. Section IV then describes the day-to-day activities of these supervisory teams, including monitoring, examinations, and broader supervisory programs, as well as the outcomes of that work.

\section{Goals and Structure of Supervision}

\section{II.A Authority, Goals and Strategy}

The Federal Reserve's authority to conduct prudential supervision of BHCs is based on law and regulation, while the implementation of the Federal Reserve's prudential supervisory authority - how supervisors monitor and assess BHCs' activities and take corrective action where needed - is based on a combination of law, regulation and accepted practice.

The principal source of the Federal Reserve's authority to supervise BHCs is found in Section 5 of the Bank Holding Company Act of 1956, as amended (the BHC Act), which provides that all BHCs are to be supervised on a consolidated basis by the Federal Reserve (Board of Governors of the Federal Reserve System 2015a). The BHC Act authorizes the Federal Reserve to collect information and to issue regulations and orders as are necessary to carry out the purposes of, and prevent evasions of, the BHC Act. The stated purposes of the BHC Act include supporting safety and soundness of BHCs, BHC compliance with applicable laws, and the stability of the U.S. financial system. In addition to the BHC Act, federal law gives the Federal Reserve authority to take action against a BHC "to prevent these entities from engaging in unsafe or unsound practices or to address violations of law in connection with their business operations” (Board of Governors of the Federal Reserve System 2015a). Federal law also 
specifies the kinds of steps supervisors may take to remedy violations of law, regulation or agreements, or when the BHC is engaging (or about to engage) in practices that the supervisor deems to be unsafe or unsound. Finally, the Dodd-Frank Act further enhanced the Federal Reserve's prudential supervisory authority including the authority to establish enhanced prudential standards for the largest BHCs to ameliorate the risks they pose to the financial stability of the United States.

As stated in various Federal Reserve System documents, the broad goals of prudential supervision relate very closely to the Federal Reserve's financial stability responsibilities. For instance, the Bank Holding Company Supervision Manual states that "the Federal Reserve's consolidated supervision activities closely complement its other central bank responsibilities, including the objectives of fostering financial stability and deterring or managing crises” (Board of Governors of the Federal Reserve System 2015a), while the 2015 Dodd-Frank stress test report notes that "through its supervision, the Federal Reserve promotes a safe, sound, and stable banking system that supports the growth and stability of the U.S. economy" (Board of Governors of the Federal Reserve System 2015b). Similarly, the description of FISG on the FRBNY public website notes that "the objectives of supervision are to evaluate, and to promote, the overall safety and soundness of the supervised institutions (micro-prudential supervision), the stability of the financial system of the United States (macro-prudential supervision), and compliance with relevant laws and regulations" (Newyorkfed.org 2014). In all these cases, the goals of supervision include the stability of the financial system in addition to the safety and soundness of individual financial institutions.

These goals are quite broad and could be implemented using a variety of supervisory strategies. These documents also detail the strategies that the Federal Reserve follows to achieve these financial stability-related goals. For instance, the Federal Reserve's policy statement about supervision of large financial institutions (SR 12-17) states that "the consolidated supervision framework has two primary objectives: (1) Enhancing resiliency of a firm to lower the probability of its failure or inability to serve as a financial intermediary. [...] This requires financial resilience by maintaining sufficient capital and liquidity, and operational resilience by maintaining effective corporate governance, risk management, and recovery planning. (2) Reducing the impact on the financial system and the broader economy in the event of a firm's failure or material weakness. [...] This requires, among other things, effective resolution 
planning that addresses the complexity and the interconnectivity of the firm's operations” (Board of Governors of the Federal Reserve System 2012). The Board of Governor's public website elaborates that the Federal Reserve's approach to the supervision of systemically important financial institutions involves "an interdisciplinary and cross-firm perspective [...] This approach [...] fosters rigorous supervision of individual firms while formalizing the use of horizontal reviews and analyses of activities and risks across the portfolio. Further, the approach promotes the evaluation of systemic risks posed by firms [...] through the evaluation of macroeconomic and financial risks, and how those risks could affect individual firms and the financial system collectively.” (Federalreserve.gov 2015a).

FRBNY documents provide additional detail on the System's strategic approach to supervision. In overseeing individual financial institutions, "FISG takes a risk-focused approach based on a supervisory plan that is customized to a firm's risk profile and organizational structure. Examiners look at key aspects of a supervised firm's businesses and risk management functions to assess the adequacy of the firm's systems and processes for identifying, measuring, monitoring and controlling the risks the firm is taking. [...] In addition, FISG evaluates the adequacy of a firm's capital and liquidity” (Newyorkfed.org 2014). As noted in other statements about the Federal Reserve’s approach to supervision: “The goal of the risk-focused supervision process is to identify the greatest risks to a banking organization and assess the ability of the organization's management to identify, measure, monitor, and control those risks” (Board of Governors of the Federal Reserve System 2005).

As described in these statements, the Federal Reserve's supervisory strategy combines a focus on the supervised firm's internal processes and governance with an independent supervisory assessment of its financial strength, especially capital and liquidity. For the first aspect, the emphasis is on the supervised firm's ability to identify and manage its risks, with subsequent supervisory actions intended to make the institution remediate any shortcomings. The motivation for this approach is to try to ensure that financial institutions, especially the largest and most complex, have financial and operational resiliency under a variety of potential stressful circumstances (Board of Governors of the Federal Reserve System 2012). One underlying theme is that responsibility for risk identification and risk management rests with the supervised institution while the Federal Reserve's role is to ensure that the institution has strong processes for doing so. 
This is an explicitly micro-prudential perspective in the sense that the focus is on individual firms, even if the standards for what constitutes sound practices are based, in part, on practices observed across the range of supervised institutions. The supervisory documents also suggest that macro-prudential considerations are important, as reflected in the reliance on a multidisciplinary approach for supervision of large, complex financial institutions. These macroprudential concerns could affect seemingly micro-prudential supervisory strategies by, for instance, focusing on common risk exposures across firms or risk management strategies that would protect an individual institution but potentially cause harm to others (e.g., fire-sale risk).

The Federal Reserve's prudential supervisory activities are closely related to its role as a regulator of these firms. As noted above, prudential supervision is inter-linked with, but distinct from, regulation of these firms, which involves the development and promulgation of the rules under which BHCs and other regulated financial intermediaries operate. The two activities are linked because an important part of prudential supervision is verifying compliance with regulation, although as much of the prior discussion suggests, the scope of supervision is much broader than compliance alone. Beyond the link through compliance, the Federal Reserve's prudential supervisory activities are interconnected to its regulatory role through the influence that supervision has on the regulatory agenda. In particular, information about industry practice and institutional activities gained through prudential supervision can be used in developing regulations governing those activities. Regulation based on in-depth knowledge of industry practice can be more effective in achieving the desired policy outcome while minimizing unintended consequences. In addition, insights into emerging risks, new products and activities, and evolving industry practice gained through supervision can help identify areas meriting new or amended regulation. In the ideal, regulation guides supervisory activities, and supervision, in turn, provides information that allows the Federal Reserve to develop and maintain regulations that more effectively address its public policy objectives.

\section{II.B Structure: Institutions and Portfolios}

The Federal Reserve is responsible for prudential supervision of a large range of bank and nonbank financial institutions, including relatively small and non-complex commercial banks and BHCs, the U.S. operations of foreign banks, savings and loan holding companies, as well as the large, complex institutions that are the focus of this paper. These institutions differ 
significantly in size, complexity, geographic reach, and business focus. Given this diversity, Federal Reserve supervision of these firms is organized by "portfolio," where portfolios are defined as groups of broadly similar financial institutions from across the Federal Reserve System. The portfolio approach facilitates tailoring of the supervisory program to match the size and complexity of the firms in each portfolio, as well as helping to ensure that oversight of similar firms is conducted in a consistent manner and that supervision within each portfolio benefits from a cross-firm perspective (Board of Governors of the Federal Reserve System 2015a). ${ }^{5}$

The Board of Governors has the authority and responsibility for supervision of financial institutions, while the supervisory activities of the Reserve Banks are conducted under delegated authority from the Board. Within the Federal Reserve, each Reserve Bank supervises financial institutions that are located within its District; in the case of FRBNY, this includes institutions located within the Second Federal Reserve District, which includes New York, northern New Jersey, southwestern Connecticut, as well as Puerto Rico and the U.S. Virgin Islands (Newyorkfed.org 2014). There is typically substantial interaction between staff at the Board of Governors and at the Reserve Banks, both on an on-going basis and when there are concerns about a particular institution or group of institutions.

At the System level, the Large Institutions Supervision Coordinating Committee (LISCC) coordinates supervision of the largest and most complex, systemically important BHCs, U.S. operations of foreign banks, and nonbank firms designated by the FSOC. Reflecting the systemic importance of the firms in its portfolio, the LISCC has a governance structure that is distinct from the oversight of smaller and less complex firms. To begin, the LISCC is chaired by the director of the Board of Governor's Division of Banking Supervision and Regulation and is composed of senior officials from across the Federal Reserve System. The membership is multidisciplinary, including representatives for the research, markets, credit risk management, and payments, clearing and settlement areas of the Federal Reserve (Board of Governors of the Federal Reserve System 2010, 2015c; Yellen 2015). The goals of the LISCC are to provide

\footnotetext{
${ }^{5}$ Aside from the large, complex financial companies that are the primary focus of this paper, the portfolios include the Large Banking Organization (LBO) portfolio, which includes BHCs with assets greater than $\$ 50$ billion, other than the largest and most complex; the Foreign Banking Organization (FBO) portfolio; the Regional Banking Organization (RBO) portfolio, which includes regional banking companies; and the Community Banking Organization (CBO) portfolio, which includes the smallest and least complex BHCs and banks.
} 
strategic and policy direction for supervisory activities involving firms in the LISCC portfolio, to enhance the consistency and quality of supervision of these firms, and to incorporate systemic risk considerations into the supervisory program (Federalreserve.gov 2015a, Board of Governors of the Federal Reserve System 2015c). There are currently 16 large, complex organizations in the LISCC portfolio, 12 of which are in the Second Federal Reserve District and thus subject to supervision by FRBNY. ${ }^{6}$

The primary operational arm of the LISCC is the Operating Committee (OC), which like the LISCC has a multidisciplinary membership from across the Federal Reserve System (Board of Governors of the Federal Reserve System 2010, 2015c). The OC, in consultation with the LISCC, establishes priorities in terms of areas of supervisory focus at individual firms and groups of firms; oversees supervisory activities for firms in the LISCC portfolio; identifies common risks facing firms in the portfolio; fosters deeper understanding of business strategies among the firms; and makes decisions about certain supervisory actions to address safety and soundness concerns at these institutions (Dudley 2014). The OC has various subcommittees that focus on current and emerging risks, operating performance, capital, and supervisory planning. Membership of the sub-committees consists of OC members as well as other staff from the Board of Governors and Reserve Banks (Board of Governors of the Federal Reserve System 2015c).

The structure of the FRBNY Financial Institution Supervision Group mirrors the portfolio structure discussed above to a large degree. As illustrated in Figure 1, there were about 675 staff members in FISG at year-end 2014, about 75 below the peak reached at the end of 2011. As shown, FISG staff has grown since the early 1990s, with a large increase during the early 1990s following the passage of legislation giving the Federal Reserve additional supervisory responsibility for foreign banking activities. This increase was followed by a gradual decline in the later 1990s reflecting staffing efficiencies from technological

\footnotetext{
${ }^{6}$ These organizations are American International Group, Inc.; Bank of America Corporation; The Bank of New York Mellon Corporation; Barclays PLC; Citigroup Inc.; Credit Suisse Group AG; Deutsche Bank AG; General Electric Capital Corporation; The Goldman Sachs Group, Inc.; JP Morgan Chase \& Co.; MetLife, Inc.; Morgan Stanley; Prudential Financial, Inc.; State Street Corporation; UBS AG; and Wells Fargo \& Company (Federalreserve.gov 2015a). Of these, American International Group, Inc.; The Bank of New York Mellon Corporation; Barclays PLC; Citigroup Inc.; Credit Suisse Group AG; Deutsche Bank AG; General Electric Capital Corporation; The Goldman Sachs Group, Inc.; JP Morgan Chase \& Co.; MetLife, Inc.; Morgan Stanley; and UBS AG are in the Second Federal Reserve District.
} 
improvements (e.g., greater automation and advances in information processing leading to reductions in administrative staff), changes in the structure of firms in the District during the consolidation wave of the late 1990s, as well as from the advent of risk-focused supervision. FISG staff is organized into departments that are responsible for different aspects of the supervision of large, complex financial institutions. These include departments containing examiners assigned to specific financial institutions or groups of financial institutions, departments containing analysts focusing on different dimensions of financial institution and banking industry risk and performance, and a department focused on policy development.

\section{Figure 1: Time series of FRBNY FISG headcount}

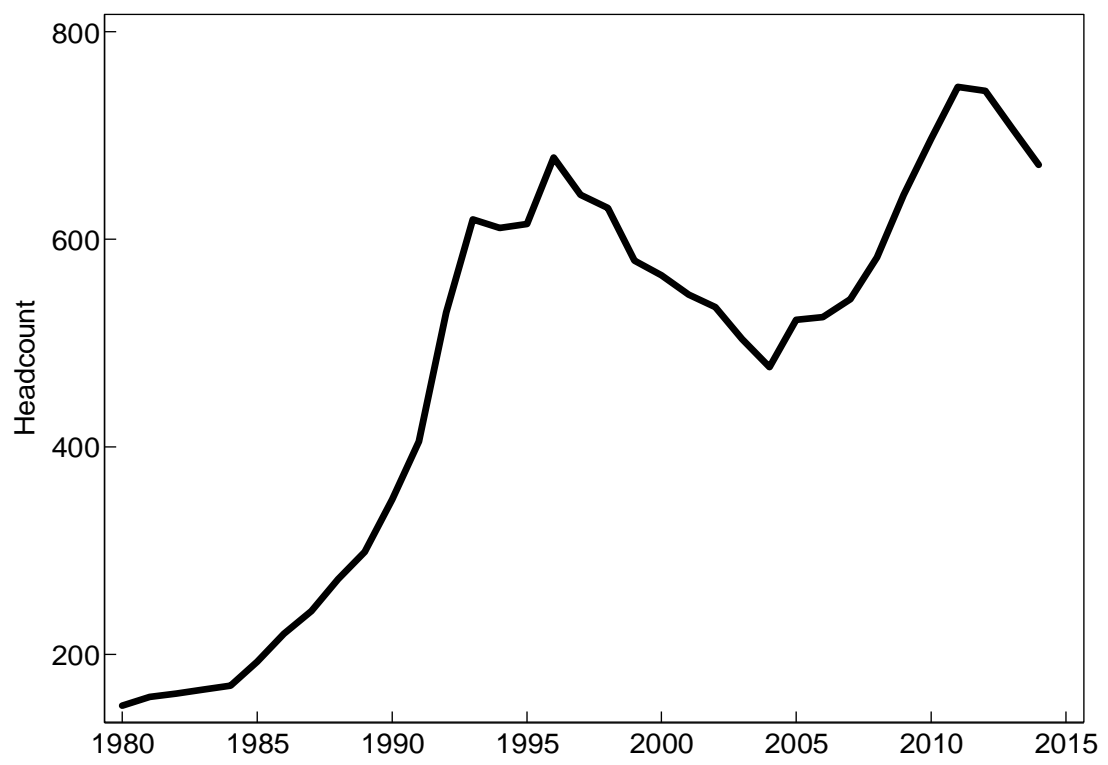

Notes: Number of full-time equivalent employees each year. Source: FRBNY internal supervisory headcount data.

Figure 2 shows FISG staff department allocations by headcount as of the end of 2014. In particular, the Complex Financial Institutions (CFI), Large International Financial Institutions (LIFI), Financial Market Infrastructure (FMI), and Regional, Community and Foreign Institutions (RCFI) departments contain staff focused on different sets of individual institutions. The Enterprise Risk Supervision (ERS) function houses analysts focusing on different facets of risk. The Cross Firm Perspective and Analytics (CFPA) function focuses on cross-firm analysis of performance and capital to provide industry-wide insights. "Other" includes the executive 
function, group operations and Supervisory Policy, which works on the development of policy related to supervisory matters in both the domestic (U.S.) and international context. Interaction among these different areas is discussed in detail in the next section. ${ }^{7}$

\section{Figure 2: FRBNY FISG staff department allocation in 2014 based on headcounts}

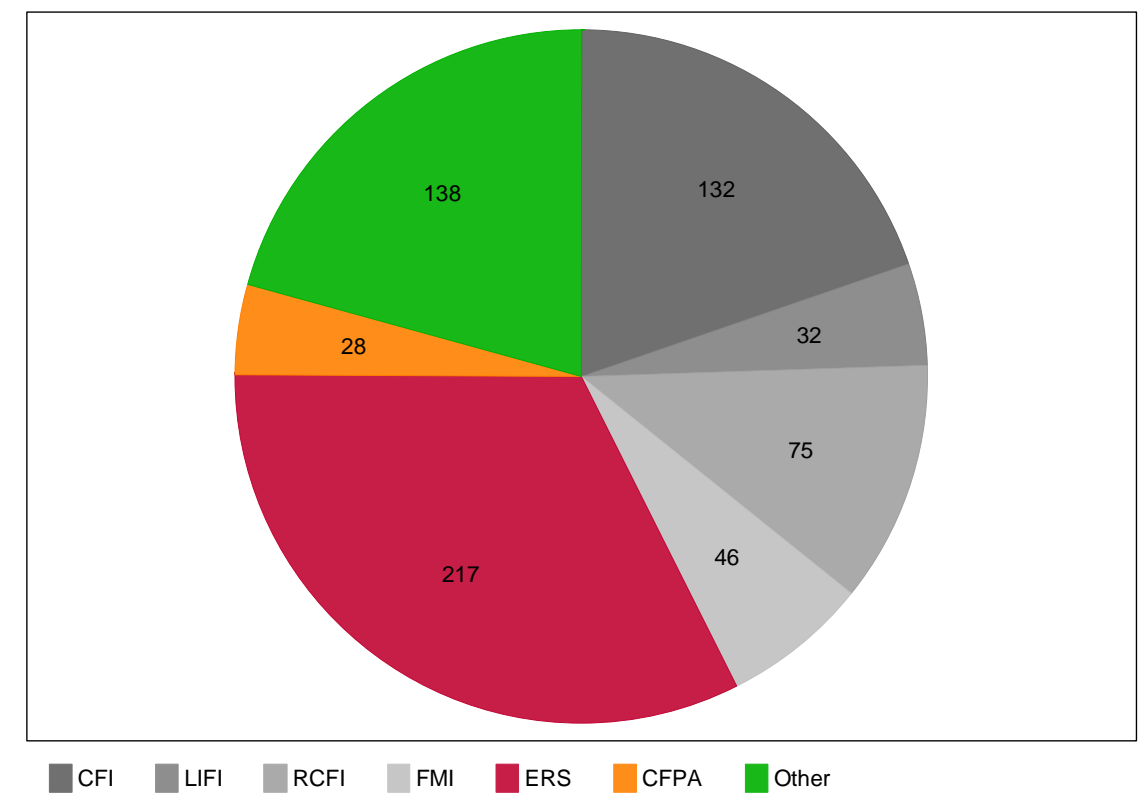

Notes: Firm-focused staff (grey areas) is divided into: CFI is Complex Financial Institutions; LIFI is Large International Financial Institutions; FMI is Financial Market Infrastructure; RCFI is Regional, Community and Foreign Institutions. ERS is Enterprise Risk Supervision; CFPA is Cross Firm Perspectives and Analytics. “Other” category includes Executive Function (11), Group Operations (119) and Supervisory Policy (8). Source: FRBNY internal supervisory headcount data.

\section{Organization: How is FRBNY Supervisory Staff Organized?}

\section{III.A Overview}

The current structure and organization of FRBNY FISG supervisory staff dates from a significant reorganization that took place in 2011. That reorganization drew on lessons learned during the financial crisis to reshape the internal structure of the group and the way that staff interacts with one another to enhance communication and facilitate identification of emerging

\footnotetext{
${ }^{7}$ Group Operations includes about 40 staff members in the supervisory development programs of new hires for examiners and risk specialists.
} 
risks through a greater emphasis on cross-firm perspectives. The reorganization was designed to foster enhanced and more frequent engagement between senior supervisory staff and senior managers and members of the board of directors at supervised firms (Dahlgren 2011).

To these ends, staff engaged in the prudential supervision of large bank and nonbank financial companies at FRBNY is assigned to one of two types of groups: firm-focused teams focused on individual companies or portfolios of companies (grey areas in Figure 2) or $\underline{\text { risk }}$

departments focused on a particular type of risk facing these firms (red area in the figure). ${ }^{8}$ While on an organizational chart, the two sets of groups are distinct, in practice there is considerable interaction between the firm-focused teams and the risk departments, including having some risk department members assigned to firm-focused teams on a long-term basis. This section describes the structure of the firm teams and risk departments, the various roles that different team and department members play, and the way that staff interacts across teams and departments. The discussion also highlights how the structure varies based on the size and complexity of the bank holding company or nonbank firm being supervised.

\section{III.B Firm-Focused Supervisory Teams}

The largest and most complex bank and nonbank financial companies supervised by FRBNY have dedicated teams of staff whose primary responsibility is supervision of the firm (Newyorkfed.org 2014). These firms include nine domestic and foreign banking companies that are part of the LISCC portfolio, three large bank holding companies that are part of the LBO portfolio, and three systemically important nonbank financial firms that have been designated by the FSOC for supervision by the Federal Reserve. ${ }^{9}$

\footnotetext{
${ }^{8}$ As described in SR 15-7, the LISCC coordinates the supervision of firms in the LISCC portfolio; the activities of FRBNY FISG supervisory staff are conducted as part of this System-wide program. The LISCC Operating Committee is ultimately responsible for execution of the LISCC supervisory program. (Board of Governors of the Federal Reserve System 2015c).

${ }^{9}$ Collectively, these firms form the Complex Financial Institutions (CFI) group of FISG. As of September 2014, the LISCC firms in the CFI portfolio were The Bank of New York Mellon Corporation, Citigroup Inc., The Goldman Sachs Group, Inc., JP Morgan Chase \& Co., Morgan Stanley, and the U.S. operations of Barclays PLC, Credit Suisse Group AG, Deutsche Bank AG, and UBS AG, as well as the nonbank firms American International Group, Inc., General Electric Capital Corporation, and MetLife, Inc. The LBO firms in the CFI portfolio are American Express Company, CIT Group Inc., and M\&T Bank Corporation.
} 
Each firm-focused team is headed by a Senior Supervisory Officer (SSO) - typically a Senior Vice President with experience in supervision, technical expertise associated with the firm's primary business activities, and/or experience in the banking industry - assisted by a Deputy Supervisory Officer (DSO). The SSO oversees the supervisory program for the firm and is the point of contact for the firm's CEO and board of directors; for foreign banking companies, the SSO may interact with the global senior executive group ("C-suite") and directors, as well as those overseeing the firm's U.S. operations. The SSO also interacts regularly with other FRBNY SSOs and with those holding similar positions at other Reserve Banks (known as Central Points of Contact, or CPCs). The DSO is responsible for the day-to-day management of the team, including logistics and resources, and meets regularly with firm officers the next level down from the CEO.

Table 1: FRBNY FISG full-time equivalent headcount based on actual hours in 2014

\begin{tabular}{|c|c|c|c|c|c|c|}
\hline \multicolumn{7}{|c|}{ Firm-focused (CFI) Team Staff: LISCC firms } \\
\hline Total & Average & Median & Min & $\operatorname{Max}$ & & \\
\hline 129 & 13 & 11 & 9 & 21 & & \\
\hline \multicolumn{7}{|c|}{ Risk (ERS) Department Staff: LISCC firms } \\
\hline Total & Average & Median & Min & $\operatorname{Max}$ & & \\
\hline 99 & 9 & 10 & 0 & 18 & & \\
\hline \multicolumn{7}{|c|}{$\begin{array}{c}\text { Total Risk (ERS) Department Staff } \\
\end{array}$} \\
\hline All & $\begin{array}{l}\text { Credit } \\
\text { Risk }\end{array}$ & $\begin{array}{l}\text { Funding } \\
\& \\
\text { Liquidity } \\
\text { Risk }\end{array}$ & $\begin{array}{l}\text { Legal \& } \\
\text { Compliance } \\
\quad \text { Risk }\end{array}$ & $\begin{array}{c}\text { Market \& } \\
\text { Counterparty } \\
\text { Risk }\end{array}$ & $\begin{array}{c}\text { Model } \\
\text { Risk }\end{array}$ & $\begin{array}{l}\text { Operational } \\
\quad \text { Risk }\end{array}$ \\
\hline 262 & 55 & 38 & 40 & 66 & 27 & 35 \\
\hline
\end{tabular}

Notes: This table shows a measure of full-time equivalent headcount based on actual hours worked by FRBNY FISG staff on CFI firm-focused teams and risk departments assigned to firms in the LISCC portfolio supervised by FRBNY. Figures are rounded to the nearest whole number. Average, median, minimum and maximum are measured across firms in the LISCC portfolio. Source: FRBNY internal supervisory time allocation data.

As shown in the top panel of Table 1, the firm-focused teams for firms in the LISCC portfolio had the equivalent of between 9 and 21 staff assigned directly to the team, with an average team size of 13, based on actual hours worked in $2014 .^{10}$ The number of team members generally corresponds to the size and complexity of the firm. Aside from the SSO and DSO,

\footnotetext{
${ }^{10}$ Internal supervisory allocation data are self-reported by employees and require subjective work classification leading to some potential measurement error in the tables and figures that rely on this data source.
} 
firm-focused team members fill one of three roles: financial analyst, business line specialist, or corporate function specialist. Financial analysts specialize in assessing the firm's financial condition, including earnings, capital and liquidity, and interact regularly with the company's chief financial officer (CFO). Business line specialists are responsible for understanding the firm's business strategy and performance in its major business lines and interact with the heads

of those business lines. Corporate function specialists interact with the firm's chief operating officer (COO) and staff, and are responsible for understanding a range of governance and operational activities, including the firm's resolution and recovery planning, incentive compensation structure, and enforcement action responses. The precise composition of the team across these three specialties reflects the size and complexity of the firm and the span of its businesses and activities.

\section{III.C Risk Department Specialists}

In addition to staff assigned directly to the team, teams for the largest and most complex companies have specialists from the Enterprise Risk Supervision department assigned to the team on a long-term basis. These risk specialists have reporting responsibilities to both the SSO and to the head of the risk department. The risk specialists are responsible for understanding the firm's risk exposures and risk management along several dimensions, including credit, liquidity, operational and market risk. Risk specialists also participate in cross-firm assessments of market developments, emerging risks, and risk management approaches. The work of risk specialists assigned to firms in the LISCC portfolio is also coordinated through the Risk Secretariat, a subgroup of the LISCC Operating Committee charged with reviewing and evaluating risk management practices and helping to prioritize risk-related supervisory activities across the LISCC portfolio (Board of Governors of the Federal Reserve System 2015c).

The number of risk specialists assigned to each firm-focused team and the particular risks covered by those specialists vary according to the business focus and risk exposure of the firm, but, comparing the upper- and mid-panels of Table 1, typically risk specialist teams assigned at LISCC firms are about 45 percent of the total team assigned to the firm (firm-specific and risk). Risk specialists are most commonly assigned to teams supervising BHCs in the LISCC portfolio, though even on these teams, not every risk type is covered by a specialist from one of the risk departments. For those risk types, and on the teams without risk specialists, other team members 
are responsible for understanding the firm's exposure to and management of the risk in question. In addition, a limited number of risk specialists are assigned to other supervisory teams, including those for the systemically important nonbank companies and the larger LBO portfolio firms (e.g., a retail credit risk specialist on the American Express team).

The risk departments cover a range of risks facing large, complex financial institutions. In particular, there are risk departments specializing in liquidity risk, credit risk, operational risk, legal and compliance risk, market and counterparty risk, and model risk. The bottom panel of Table 1 displays the allocation of staff by risk categories based on actual-hours-equivalent headcounts during 2014. Within each risk type, department members may focus on particular aspects of the risk in question. For example, the credit risk team has sub-specialists in wholesale credit (large loans to corporations or loans associated with commercial real estate) and in retail/consumer credit. The market and counterparty risk team has specialists in particular types of trading products, such as foreign exchange, interest rate products, equities or commodities.

The risk specialists assigned to the firm-focused teams represent a large share of the risk departments' staff. In addition to the risk specialists, the risk departments have in-house supervisory and analytical staff. These staff members are responsible for cross-firm analysis, targeted work at a particular firm at the request of an SSO, and coverage of portfolios of firms whose teams do not have dedicated risk specialists. Several risk departments have analytical units that manage and analyze large data sets collected from the banks. These units include staff in the liquidity risk department working with detailed firm-specific data about the maturity, funding and cash flow characteristics of the assets, liabilities, and off-balance sheet exposures of the consolidated firm and its major legal entities ${ }^{11}$; staff in the market and counterparty department who analyze counterparty-level exposures at major derivatives dealers; and the Shared National Credit (SNC) team in the credit risk department, which plays a critical role in the interagency program examining the treatment of these large loans across banking companies. $^{12}$

\footnotetext{
${ }^{11}$ These data are collected on regulatory report forms FR 2052a and FR 2052b. See Federalreserve.gov (2015b) for more detail.

${ }^{12}$ The Shared National Credit Program was established in 1977 by the Board of Governors of the Federal Reserve System, the Federal Deposit Insurance Corporation, and the Office of the Comptroller of the Currency to provide an efficient and consistent review and classification of any large syndicated loan. Today, the program covers any loan or loan commitment of at least $\$ 20$ million that is shared by three or more supervised institutions. The agencies' review is conducted annually, usually in May and June. (Federalreserve.gov 2015c).
} 
Aside from work done by the risk teams, analysis in other areas of FISG and FRBNY also supports and is a critical input to prudential supervision of the large, complex BHCs and nonbank financial institutions at FRBNY. For instance, a separate team of analysts assesses business line revenue performance, earnings and financial performance, and capital trends at these firms. ${ }^{13}$ Work of these analysts supports the LISCC and its assessment of the large, complex firms in that portfolio, including those located outside the Second District. However, unlike the risk specialists, the "capital and performance" analysts are not integrated onto the supervisory teams. Nonetheless, their work helps shape the supervisory agenda for LISCC firms, as discussed further in Section IV.

\section{III.D Large Foreign Banks}

For large foreign firms not part of the LISCC portfolio, the structure of the supervisory teams differs somewhat. The U.S. operations of these firms are supervised by teams responsible for a portfolio of institutions rather than by teams dedicated to individual firms. As shown in Figure 2, at the end of 2014, there were 32 firm-focused supervisors assigned to the Large International Financial Institutions (LIFI) portfolio, which is composed of approximately 25 foreign banking organizations. Most of these foreign firms have a U.S. broker-dealer and more than $\$ 10$ billion in assets in the United States. LIFI staff is organized into teams that cover as few as two to as many as nine individual foreign bank organizations, with firms grouped into teams by geography (countries or global regions) and business focus. Foreign banks with more complex U.S. operations are covered by teams of two or three people, while firms with smaller or less complex U.S. operations may be covered by a single person, either alone or together with other firms from the same country or region. The LIFI teams do not have embedded risk specialists, although teams may consult with or get assistance from the various risk departments. For instance, some LIFI teams use the results of the credit risk department's SNC review as an important part of their assessment of credit risk at the U.S. operations of these institutions.

\footnotetext{
${ }^{13}$ Through 2014, these analysts were part of CFPA, which as illustrated in Figure 2, had a staff of 28 at year-end 2014. Following a reorganization of FRBNY at the beginning of 2015, many of these analysts became part of a unit outside of FISG.
} 


\section{E Coordination and Information-Sharing within FISG}

Over time, supervisory staff members rotate across the firm-focused teams and, less frequently, among the risk departments. The Board of Governors requires that SSOs rotate at least every five years, with the possibility of extensions in special circumstances. Using FRBNY headcount data starting in 2000, the SSO spells at LISCC firm have generally been significantly shorter than 5 years, with an average of about 2.3 years. ${ }^{14}$ The tenure limit is applied to all firmfocused team members in FISG, including the risk specialists. Thus, it is common for individuals to move from team to team over time, with the goal of balancing the in-depth knowledge gained about a particular firm with the fresh and independent perspective acquired by exposure to more than one institution. Rotation is intended to benefit the team as well as the individual, both by bringing in staff who do not necessarily share common assumptions with existing team members and by mitigating any tendencies to adopt the perspective of the firm being supervised. It is less common for staff to move from one risk department to another, given the specialized knowledge required to be an effective risk specialist. Risk specialists do, however, move to different firm-focused teams and into different assignments within the risk departments.

Members of both firm-focused teams and risk departments meet regularly to share information and observations and to coordinate analysis where appropriate. The most important mechanism for this interaction are the so-called "affinity groups," which are cross-firm groups of staff with common specialties and work focuses, such as financial analysts, business line analysts, and corporate function specialists. These groups generally meet weekly, with members attending in person at the FRBNY offices. Analysts and specialists from supervisory teams at other Reserve Banks and at the Board of Governors also participate in the affinity groups to facilitate information-sharing and knowledge building beyond FRBNY.

\section{F Impact of 2011 Reorganization}

As noted above, the current organization of supervisory staff for the large, complex bank and nonbank firms dates from 2011. Prior to this date, the firm-focused supervisory teams (shades of grey in Figure 2) were part of a single relationship department (Figure 3), though

\footnotetext{
${ }^{14}$ This figure excludes the most recent SSO assignments since these have not been completed and including them in the calculation would otherwise lead to a right-truncation bias.
} 
within that department, the teams were managed on a portfolio basis. More significantly, the teams focused on individual firms (known as "relationship” teams at that time) and the analysts specializing in different types of risk (known as “risk” teams) were less closely integrated. Risk specialists were not assigned to firm-focused teams on a long-term basis, but instead went from firm to firm on a project basis. SSOs (then referred to as Central Point of Contacts, or CPCs) would make requests for assistance from risk specialists to participate in firm-specific examinations; in some cases, risk specialists would work with the relationship team as part of a broader horizontal exam sponsored by the risk department and covering several firms.

\section{Figure 3: Time series evolution of FISG staff department allocation based on headcounts}

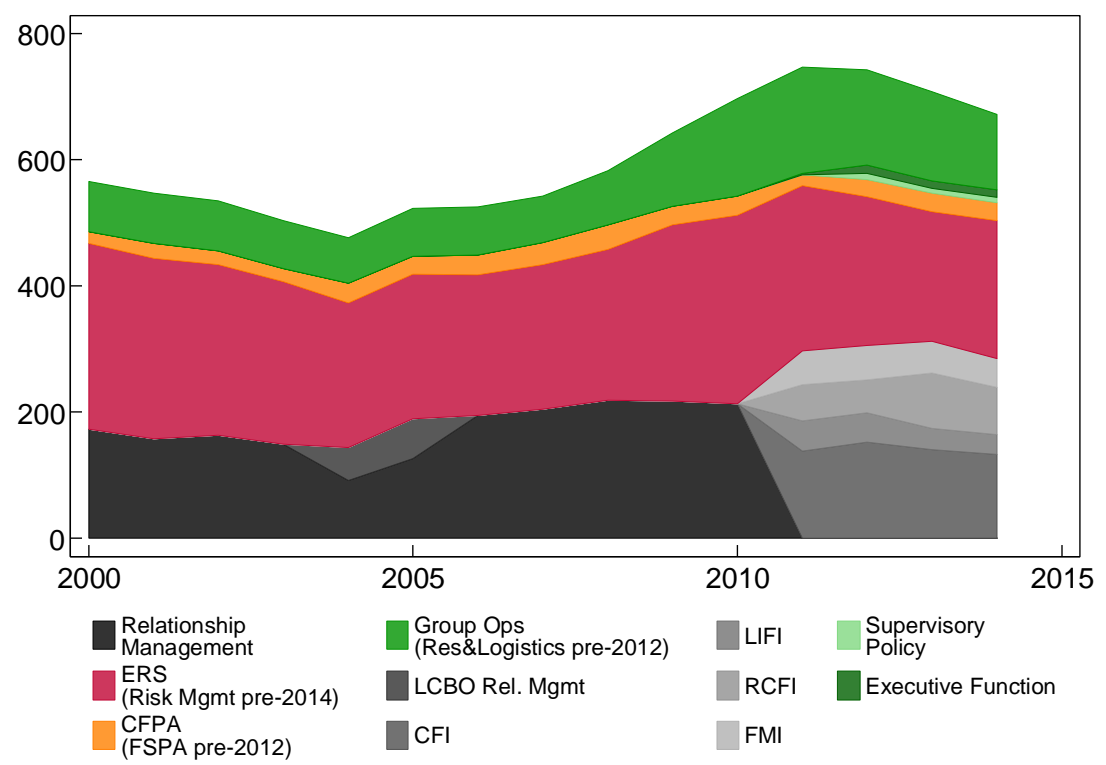

Source: FRBNY internal staff allocation data.

As a result of the reorganization, risk staff now allocates an increasing portion of their time to a single firm. Figure $\mathbf{4}$ shows the portion of the risk department staff that is assigned to a single institution, as measured by the fraction of staff devoting at least two-thirds of their time to a single firm. As illustrated in the figure, the share of risk department staff who were assigned to a single institution rose from less than 5 percent to more than 30 percent after 2011.

Further, the new organizational structure formalized the three distinct roles within each firm-focused team (financial analyst, business line analyst, and corporate function specialist). 
Under the previous structure, relationship team members covered many of the same topics addressed by the financial analysts and corporate function specialists. However, the emphasis on business line strategy and performance is a new orientation (Dahlgren 2011). This new orientation - which is consistent with guidance that applies to supervision of large, complex financial companies across the Federal Reserve ${ }^{15}$ - is intended to provide insight into how the firms are generating profits and the risks of the strategies the firms are pursuing, as a way of providing context to the evaluation of risk management and internal audit. Thus, the new approach involves a less direct focus on a firm's risk management and internal audit units as ends in themselves, and more focus on how the work of these areas support (or do not support) the firm's business strategies and risk appetite.

Until recently, firm-focused teams were "on-site" in the sense that they were located in offices at the institution they were supervising. Typically, the supervised firm would provide a separate, dedicated area for the supervisory team, with controlled access for team members. Team members also had access to work areas in FRBNY offices, so that they could work "offsite" as needed. The idea in locating firm-focused supervisory teams on-site at the supervised institutions was to provide ready access to senior management and internal systems and information networks at the supervised firm. Over time, however, technological enhancements have made access to firms' internal systems from remote locations much easier. As a result, the supervisory teams are being relocated to FRBNY offices on a permanent basis to facilitate interaction, cooperation, and information-sharing among FISG staff, as well as to foster analysts' independence. This pattern is evident in the fraction of on-site hours spent by LISCC firmfocused FISG staff shown in Figure 5, which was about 55 percent in 2014, compared to about 90 percent in the ten years prior.

\footnotetext{
${ }^{15}$ SR 12-17 describes the conceptual framework for supervision of large financial institutions, which focuses on enhancing resiliency and reducing the impact of a firm's failure. See Board of Governors of the Federal Reserve System (2012).
} 
Figure 4: Risk (ERS) department staff allocated to a single institution

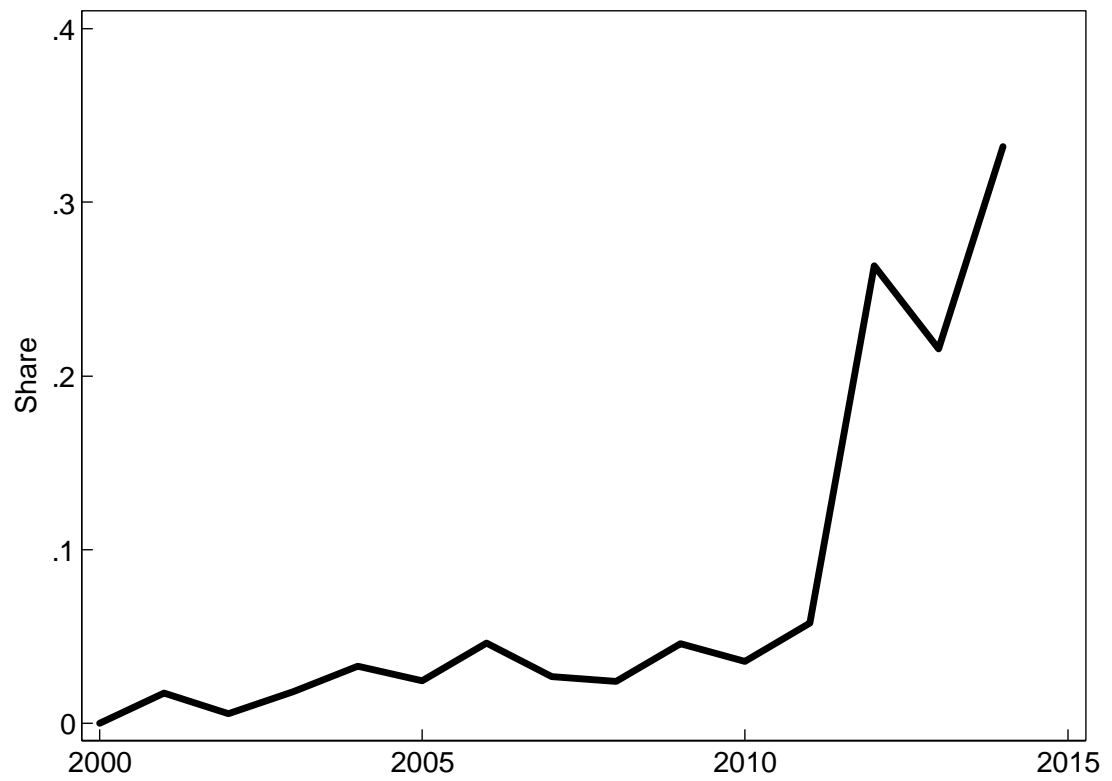

Notes: The figure shows the fraction of risk department staff that devotes at least two-thirds of their supervisory hours to a single firm. Total supervisory hours exclude absences, training, and technical assistance. Source: FRBNY internal time allocation data.

Figure 5: Fraction of hours spent by LISCC firm-focused staff on-site

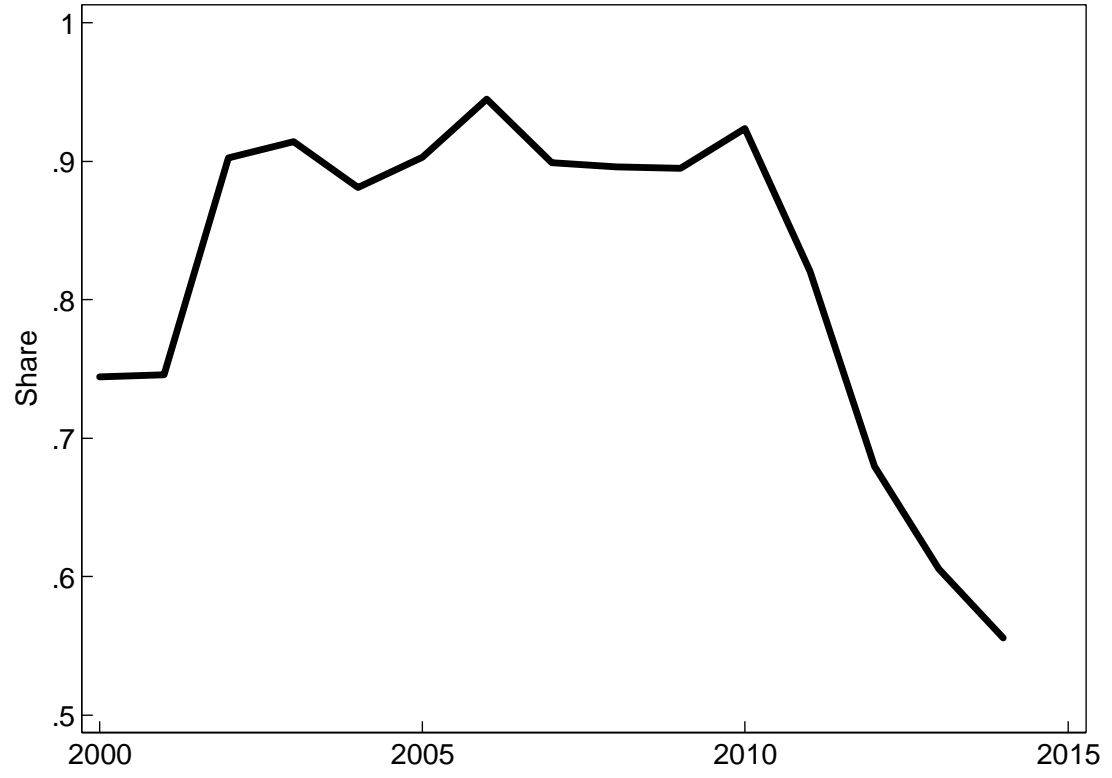

Source: FRBNY internal time allocation data 


\section{G Interaction with Other Supervisors}

The Federal Reserve is the consolidated supervisor of BHCs and systemically important nonbank financial companies, meaning that it is responsible for having an integrated view of "the organization's structure, activities, resources and risk, as well as [addressing] financial, managerial, operational or other deficiencies" (Board of Governors of the Federal Reserve System 2015a). This consolidated oversight encompasses the parent holding company and its subsidiaries. Many of these subsidiaries are themselves regulated and supervised entities, such as commercial banks, thrifts, registered broker-dealers, and insurance companies. Thus, as part of the consolidated oversight of a bank holding company, Federal Reserve supervisory staff interacts with supervisory staff from other federal agencies, including the Office of the Comptroller of the Currency, the Federal Deposit Insurance Corporation, the Securities and Exchange Commission, as well as state financial sector supervisors (for instance, the New York State Department of Financial Services). ${ }^{16}$

Federal Reserve supervisors make use of the work done by other federal and state supervisors in their oversight of commercial bank and other regulated holding company subsidiaries. Under the terms of the Gramm-Leach-Bliley Act (GLBA), Federal Reserve supervisors rely as much as possible on the examination reports of these other agencies in assessing the condition of these subsidiaries (Board of Governors of the Federal Reserve System 2015a). Beyond relying on reports, Federal Reserve supervisors meet regularly with supervisory staff from the other agencies to share information and insights about the firm and the relevant subsidiary, as well as information about supervisory plans, activities and findings. In addition to gaining the insights of other federal and state supervisors, Federal Reserve supervisors share information with these supervisors, including "information relating to the financial condition, risk-management policies, and operations of a banking organization that may have a material impact on the regulated subsidiary, as well as information concerning transactions or relationships between regulated subsidiaries and their affiliates" (Board of Governors of the Federal Reserve System 2015a).

\footnotetext{
${ }^{16}$ The Federal Reserve is the primary federal supervisor of state-chartered commercial banks that are members of the Federal Reserve System ("state member banks"). The Federal Reserve shares supervisory responsibility for state member banks with state banking or financial services supervisors. In supervising these entities, which are often subsidiaries of bank holding companies, Federal Reserve supervisory staff coordinates extensively with staff from state supervisory agencies.
} 
Federal Reserve supervisory staff also interacts with home country supervisors of foreign banking organizations (FBOs) operating in the United States. As noted in a Federal Reserve policy document describing the supervision of the combined U.S. operations of foreign banks (SR 08-9), "supervision of a large complex FBO requires cooperation and information exchange between home and host country supervisors" (Board of Governors of the Federal Reserve System 2008). In practice, this cooperation involves formal sharing of information derived from supervisory activities, generally "facilitated by an MOU [memorandum of understanding] that establishes a framework for bilateral relationships and includes provisions for cooperation during the licensing process, in the supervision of ongoing activities, and in the handling of problem institutions" (Board of Governors of the Federal Reserve System 2008). These formal arrangements are augmented by periodic visits between the Federal Reserve and home country supervisory staff that include discussion of both general topics concerning banking industry developments and "strategy sessions focusing on individual FBOs and specific supervisory issues and initiatives” (Board of Governors of the Federal Reserve System 2008).

\section{Work Content: What Do Supervisors Do?}

\section{IV.A Overview}

This section describes how supervision of large, complex bank and nonbank companies is conducted on a day-to-day basis at FRBNY. The focus of the discussion is primarily on the work of the firm-focused supervisory teams, including the risk specialists embedded on those teams, but also describes how the analytical work done by the risk departments and other crossfirm analysts is integrated into the supervision of these firms.

Most of the work of the firm-focused supervisory teams can be classified as either information-gathering and analysis or follow-up to that analysis, including assigning supervisory ratings, determining enforcement actions and subsequent remediation tracking. The section first describes the different ways in which the firm-focused teams conduct information-gathering, including continuous monitoring and examinations, as well as the range of subsequent outcomes. The section then describes how the teams determine which projects and type of monitoring to pursue, including a description of the annual supervisory planning cycle and the process of synthesizing supervisory work to assign a rating to each firm. The discussion also covers how 
priorities are set between work that is particular to an individual firm and work that covers multiple firms - known as “horizontal” work.

\section{IV.B Activities of the Supervisory Teams}

The work of the supervisory teams is guided by a series of written policies and procedures, guidance, and manuals that codify supervisory expectations and provide direction to the teams in structuring their work at the firms. These materials include the Bank Holding Company Supervision Manual, which “provides guidance for conducting inspections of bank holding companies [...] to ascertain whether the financial strength of the bank holding company is being maintained on an on-going basis and to determine the effects or consequences of transactions between a holding company or its nonbanking subsidiaries and its subsidiary banks” (Federalreserve.gov 2015d) ${ }^{17}$, as well as a series of SR Letters that address "various policy and procedural matters related to the Federal Reserve's supervisory activities” (Federalreserve.gov 2015e). ${ }^{18}$ SR Letters, which are publicly available, are intended to provide information both to supervisors and to supervised institutions. As such, the letters address a diverse range of topics, including the overall supervisory program for large, complex financial institutions (SR 12-17), recovery planning (SR 14-8), model risk management (SR 11-7), counterparty credit risk management (SR 11-10), and stress testing (SR 12-7). Finally, these public documents are supplemented by internal policies and procedures intended to provide guidance to supervisory staff in designing and implementing their supervisory work programs.

The traditional model of bank supervision involves a full-scope examination of a bank's financial condition and operations, typically conducted once a year and assessing the bank as of that moment in time. While this approach is still used for smaller banks and BHCs, for some time, the larger and more complex bank and nonbank firms have been subject to on-going supervision over the course of the year. Under the current supervisory approach, the firmfocused supervisory teams engage with management at the firm and review and analyze

\footnotetext{
${ }^{17}$ This manual, along with a similar manual focused on the supervision of commercial banks, is publicly available on the Board of Governors website, federalreserve.gov.

${ }^{18}$ According to the Board of Governors website: "Supervision and Regulation Letters, commonly known as SR Letters, address significant policy and procedural matters related to the Federal Reserve System's supervisory responsibilities. These letters are issued by the Board of Governors' Division of Banking Supervision and Regulation and are a means of disseminating information to banking supervision staff at the Board and the Reserve Banks, as well as to supervised banking organizations.” (Federalreserve.gov 2015e).
} 
information provided by the firm on a continuous basis; this on-going oversight is referred to as "continuous monitoring." The teams also engage in more detailed analyses and assessments of particular issues at different points over the course of the year, ${ }^{19}$ in the form of "enhanced continuous monitoring” and formal examinations. This more detailed information-gathering and analysis can be firm-specific and conducted by a single team, or can involve multiple banks and thus be coordinated across several teams, including in-house analyst teams in the risk departments and other areas of FISG as well as other Reserve Banks and other supervisors.

The three approaches to information-gathering - continuous monitoring, enhanced continuous monitoring, and formal examinations - differ in their goals, as well as in their structure and execution. This section discusses each of these supervisory approaches in greater detail. The conceptual and practical boundaries between the approaches are not always distinct. For instance, it can be difficult to distinguish more intense scrutiny of an issue identified via continuous monitoring from enhanced continuous monitoring, or to determine whether a particular issue should be pursued via enhanced continuous monitoring rather than via a formal, targeted examination. The following discussion thus focuses on the broad differences rather than some of the finer nuances.

\section{IV.C Continuous Monitoring}

Continuous monitoring activities are intended to enable each firm-focused supervisory team to "develop and maintain an understanding of the organization, its risk profile, and associated policies and practices” (Board of Governors of the Federal Reserve System 2015a), as well as to identify gaps or issues that might lead the team to do more in-depth analysis. Continuous monitoring involves meetings with bank management, review of internal reports, and regularly produced analysis based on firm internal data. Continuous monitoring activities are almost always focused on, and structured around, an individual firm and its particular characteristics, business focus, and management structure. In contrast, enhanced continuous monitoring and formal examinations are intended to be "deeper dives" into particular issues or concerns about the firm, involving more analytical work and leading to conclusions about the effectiveness of internal controls, risk management, or business strategies as well as an

\footnotetext{
${ }^{19}$ These more detailed assessments can occur at any point during the year, in contrast to the traditional supervisory model, in which all assessment of the bank occurs at the same "as of" date.
} 
assessment of the firm against its internal guidelines, regulatory or industry standards, or peer practice. Enhanced continuous monitoring can be less formal and more exploratory than formal examinations, but both approaches involve a focus on a particular issue that has been identified as a potential concern. Figure 6 shows the allocation of hours in 2014 expressed in headcounts of FISG staff working on firms in the LISCC portfolio.

\section{Figure 6: LISCC team FISG staff hours' headcount allocation by activity}

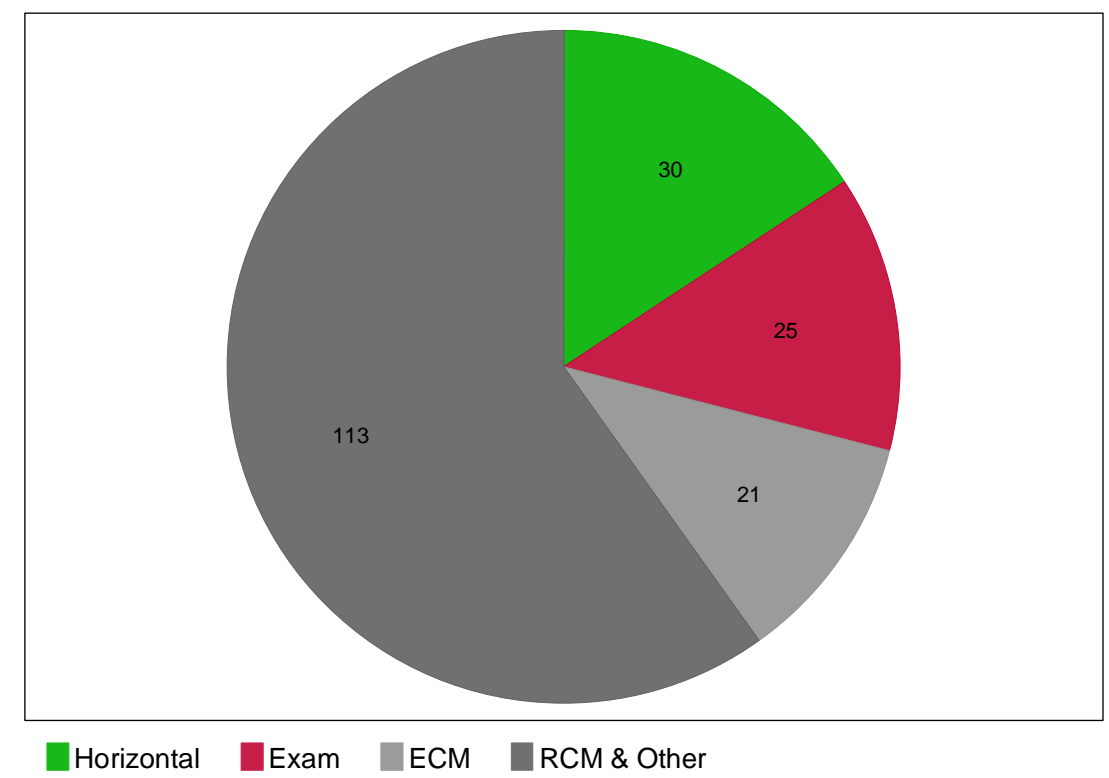

Notes: ECM is enhanced continuous monitoring; Exam is non-horizontal examination activities; Horizontal includes cross-firm programs such as the Comprehensive Capital Analysis and Review (CCAR) and Comprehensive Liquidity Analysis Review(CLAR). RCM \& Other is regular continuous monitoring and all other activities (including non-supervisory ones). Source: FRBNY internal supervisory hours allocation data.

As part of continuous monitoring, firm-focused team members have both regularly scheduled and ad hoc meetings with bank management. The regularly scheduled meetings sometimes have specific agendas focused on issues of interest to the team and sometimes are open ended to provide an opportunity for bank management to share its view of important developments. Team members may also use open ended meetings to ask questions about recent decisions or steps taken by the firm, as a way of gaining further insight into the firm's 
governance processes. ${ }^{20}$ Different team members typically meet with different levels of bank management and management whose responsibilities span different areas. For instance, as noted above, the SSO meets frequently with the firm's CEO and board members. Financial analysts meet with the firm's chief financial officer (CFO) and senior staff; the business line specialists meet with the corresponding business line managers; corporate function specialists meet most often with the chief operating officer (COO); and the risk specialists meet with internal auditors and staff at the supervised institution who report to the chief risk officer (CRO). Team members often meet with multiple individuals at the firm to discuss the same topic or ask the same questions, as inconsistent responses can be indicative of an issue at the firm. Aside from gathering information, meetings can also be used to convey feedback, especially to senior management and board members.

A second key aspect of continuous monitoring is reviewing internal data produced by the firm. These data include regulatory reports, which provide comprehensive and standardized reporting across firms and over time; internal reports providing customized, nuanced reporting by the firm using metrics developed for internal management purposes; and external reporting, such as financial statements. The teams have the authority to request any report or data produced by the firm and, as a matter of practice, regularly receive a very large number of internal reports and analyses as well as access to the firms' internal reporting systems. Reports provided to business line managers, senior managers, and the board of directors are of particular interest, since these reports provide insight into the information available to decision-makers at the firm and thus into the decision-making process. Aside from these reports, the teams also receive daily, weekly, monthly and quarterly reports containing business line, risk management, and other internal control metrics, frequently containing very detailed information about the firm's performance, risk exposures, and internal oversight.

One challenge faced by the teams is the large volume of information that is provided, which increases the difficulty of conducting comprehensive, detailed assessment of the material. Much of the review of the regular management reports focuses on identifying changes and new developments; these assessments can provide topics for discussion in meetings with the firm and/or spur further exploration and analysis. Analysis provided by the in-house risk departments

\footnotetext{
${ }^{20}$ In these settings, team members might ask questions such as "How did you get comfortable with that decision?" or "How did you gather the information to make that choice? What analysis did you do?"
} 
and analysts in other parts of FISG and FRBNY complements analysis of internal management reports done by team members. For instance, analysis of the detailed liquidity data by the liquidity risk department can identify changes in a firm's liquidity position or liquidity risk profile that might lead to discussion with the firm and further analysis and exploration by the team or the liquidity risk department.

\section{IV.D Enhanced Continuous Monitoring and Examinations}

In contrast to continuous monitoring, which consists of on-going, repeated activities of the firm-focused supervisory teams, enhanced continuous monitoring and formal examinations involve discrete supervisory "projects" that are generally conducted on a one-time basis. As noted above, enhanced continuous monitoring is intended to provide insight into a particular topic, business strategy, risk levels and/or risk management practices and controls. It can also be used to learn more about an area or fill a knowledge gap. As such, it is a "deeper dive" into an issue or question that has already been identified, seeking to understand the scope and depth of the issue and whether further information-gathering and analysis or remedial actions on the part of the firm are warranted. Enhanced continuous monitoring could involve more extensive meetings with firm management to discuss particular issues or topics in detail (i.e., with specific, pre-planned agendas); special data requests for information that goes beyond that provided in the internal management reports normally received by the team; limited testing of individual transactions to assess compliance with internal policies, supervisory guidance, and/or regulation; and assessment and documentation of the information gathered. Enhanced continuous monitoring can be focused on issues specific to an individual firm, or can be used to develop a horizontal, cross-firm perspective on an area or topic.

The results of enhanced continuous monitoring vary according to the nature of the particular project and what is discovered during the exercise. For instance, enhanced continuous monitoring exercises that are aimed at filling knowledge gaps result primarily in enhanced information and understanding by the supervisory team. Review of the findings and communication back to the firm could be limited and informal in these cases. In contrast, enhanced continuous monitoring projects that are intended to explore control or risk management weaknesses at one or more firms could result in formal or informal enforcement actions ranging from supervisory observations to public "cease and desist" orders. In these latter cases, there 
would be extensive vetting (review) of the findings by supervisory team members, by one or more of the risk departments, by more senior management within FISG, and by the LISCC Operating Committee for companies in the LISCC portfolio. The outcomes would be communicated to the firm in writing, with subsequent tracking and follow-up by the firmfocused team to ensure that the deficiencies that have been identified are being addressed.

Formal examinations also involve a "deep dive” into a particular topic or issue affecting one or more firms. There are several types of examinations, including target examinations, which focus on making an assessment of a firm's practices against its internal guidelines, regulatory or industry standards or peer practice; discovery examinations, which focus on "understanding of a particular business activity or control process - for example, to address a knowledge gap identified during the risk assessment or other supervisory process" (Board of Governors of the Federal Reserve System 2015a); and horizontal examinations that involve coordinated examination work across several institutions. Procedurally, target examinations involve several stages, including introductory letters sent to the banks notifying them of the examination and requesting information, a "scope" memo that defines the rationale and objectives of the examination, including questions to be answered and procedures to be performed, memos documenting the findings and conclusions ("product memos"), meetings with the firms to present the results verbally ("close-out meetings"), and a formal examination report communicating findings to the firm. Depending on the focus, examinations can also involve more extensive transaction testing than is typically done during enhanced continuous monitoring. Each stage of the examination process is vetted by various participants and management within FISG and, for horizontal examinations, with System oversight groups.

Both in terms of objectives and based on the work done, it can be difficult to distinguish some forms of enhanced continuous monitoring from formal examinations. Both involve a thorough analysis and assessment of a particular issue or area accompanied by extensive information-gathering, either at an individual firm or across several firms; the actual activities carried out - meetings, information requests, testing and analysis - can be identical. Both can result in enforcement actions requiring substantive change in processes, governance, and activities at the firm. The primary difference between the two approaches has to do with the level of formality and structure involved in the exercise. Typically, examinations are significantly more structured and can take much longer to get started and to complete than 
enhanced continuous monitoring. Enhanced continuous monitoring is thus often favored by the supervisory teams over formal examinations because it is more flexible and can be timelier. That said, the structure and formality of a formal examination can mean that resources (principally, the time of team members) are officially allocated to the exam, whereas staffing of enhanced continuous monitoring is more fluid.

As noted, both enhanced continuous monitoring and examinations tend to be discrete exercises carried out on a one-time basis. The Federal Reserve also sponsors several large horizontal supervisory programs that involve similar activities but that occur on an annual or ongoing basis. These programs include the Comprehensive Capital Analysis and Review (CCAR), which focuses on internal capital planning and capital adequacy; the Comprehensive Liquidity Analysis and Review (CLAR), which focuses on internal liquidity planning and liquidity resources (Tarullo 2014); and the Supervisory Assessment of Resolution and Recovery Preparedness (SRP), Federal Reserve's annual horizontal review of the LISCC firms' options to support recovery and progress in removing impediments to orderly resolution (Board of Governors of the Federal Reserve System 2015c). While many of the activities conducted under these programs are similar to those involved in enhanced continuous monitoring and horizontal examinations, there are some important distinctions. The programs can involve more firms than would typically be involved in a horizontal exam - the CCAR, for instance, includes 31 firms spanning the LISCC and Large Banking Organization (LBO) portfolios. Both CCAR and CLAR are the primary lens through which capital and liquidity adequacy at the participating firms are assessed (which is why they are "comprehensive” analyses and reviews), whereas a typical target examination is more narrowly focused. In some cases, the programs also have their own distinct set of possible remedial actions, including having the Federal Reserve object to a firm's capital plan in the CCAR (in which case its ability to pay dividends and make share repurchases is restricted) and the possibility of requiring substantial structural changes at a firm whose resolution plan is deemed not credible.

\section{IV.E Remedial Steps and Follow-up}

Aside from follow-up consequences specific to these large, horizontal programs, both the programs and day-to-day supervision conducted by the firm-focused supervisory teams can result in a range of supervisory actions intended to make firms address shortcomings identified 
through the supervisory process. When the information-gathering and analysis conducted as part of regular or enhanced continuous monitoring, examinations, or a supervisory program reveal deficiencies in a firm's risk management, governance, or other controls, or if a firm is found to be in a financial condition that threatens its safety and soundness, then supervisors can take various actions to compel the firm to address the deficiencies. These supervisory actions generally take the form of written communication to the firm's board of directors or an executive-level committee of the board (Board of Governors of the Federal Reserve System 2013).

Figure 7 shows the incidence of occurrence, and type, of supervisory actions for all LISCC institutions supervised by FRBNY between 2011 and 2014.

\section{Figure 7: Supervisory actions issued to LISCC institutions in the Second Federal Reserve District Jan2011-Nov2014}

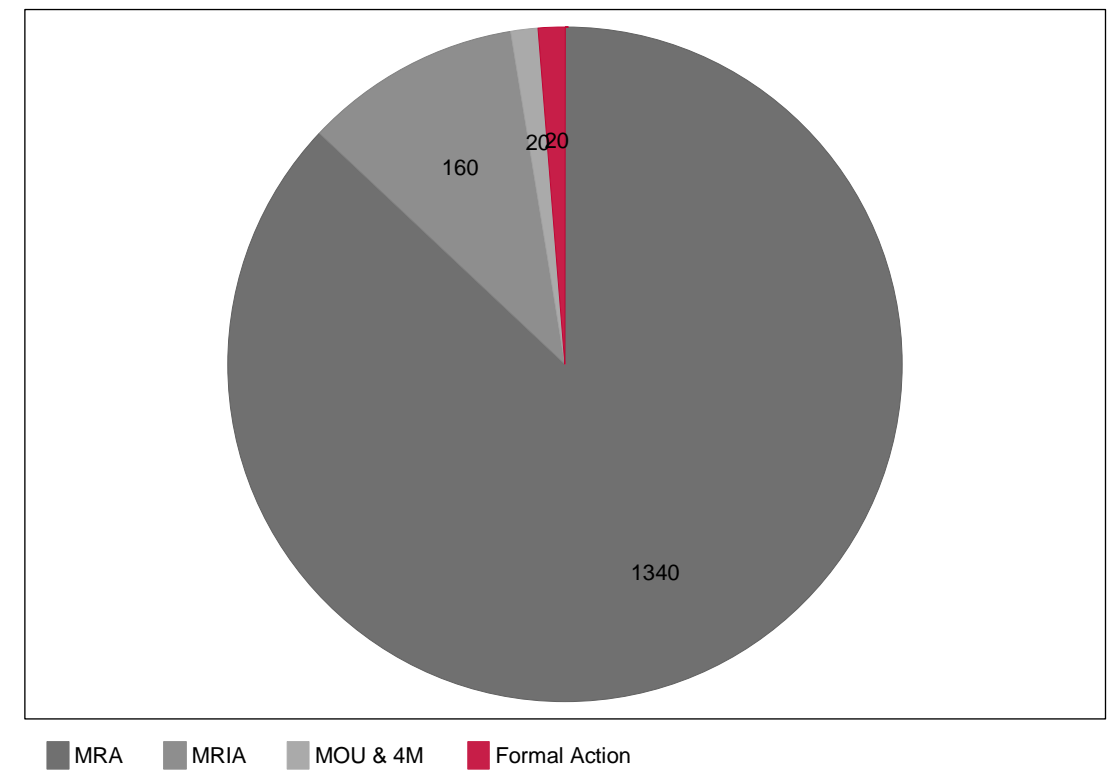

Notes: All counts are rounded to the nearest ten. The chart shows the number of supervisory actions issued to LISCC financial institutions supervised by FRBNY between January 2011 and November 2014, irrespective of whether the action is ongoing (open) or resolved (closed). Grey areas include MRAs (matters requiring attention), MRIAs (matters requiring immediate attention), MOUs (memoranda of understanding) and 4Ms (4(m) agreement). Formal enforcement actions include cease and desist (C\&D), written agreements and other formal actions. Source: FRBNY internal data on enforcement activity.

The mildest of these supervisory actions are matters requiring attention (MRAs) and matters requiring immediate attention (MRIAs). MRAs and MRIAs are considered "informal" 
actions, in the sense that the Federal Reserve's authority to impose these actions is based on supervisory practice as described in various SR Letters. As shown in Figure 7, MRAs are about 8 times as frequent as MRIAs. According to SR Letter 13-13, MRIAs are "matters of significant importance and urgency that the Federal Reserve requires banking organizations to address immediately and include: (1) matters that have the potential to pose significant risks to the safety and soundness of the banking organization; (2) matters that represent significant noncompliance with applicable laws or regulations; [and] (3) repeat criticisms that have escalated in importance due to insufficient attention or inaction by the banking organization" while MRAs "constitute matters that are important and that the Federal Reserve is expecting a banking organization to address over a reasonable period of time, but the timing need not be 'immediate'." The distinction between an MRA and MRIA is the "nature and severity of the matters requiring corrective action" and the "immediacy with which the banking organization must begin and complete corrective actions.”

The MRA or MRIA specifies the particular concern being raised as well as a timeframe by which the firm must remediate the deficiency. Firms receiving MRAs or MRIAs will typically develop a plan for remediating the shortcomings being raised; the supervisory team then reviews the plans and is responsible for following up to ensure that the firm has followed it. This follow-up can take the form of a subsequent examination or regular or enhanced continuous monitoring. If the firm fails to address sufficiently the deficiency identified in the MRA or MRIA, then the matter can be escalated into more severe enforcement actions (Board of Governors of the Federal Reserve System 2013). It is typical for a banking organization to have many outstanding MRAs and MRIAs at any given time, reflecting the outcomes of the range of supervisory activities undertaken by the firm-focused supervisory team and other Federal Reserve supervisory staff.

Aside from MRAs and MRIAs, informal supervisory actions also include Memoranda of Understanding (MOUs). Figure 7 shows the joint incidence of MOUs along with the formal supervisory actions known as $4(\mathrm{~m})$ agreements (“4Ms”21). MOUs and $4 \mathrm{Ms}$ are distinct but are grouped together in the table as they are most severe actions that are not publicly disclosed. An MOU is considered to be more severe than an MRA or MRIA, typically encompassing multiple

\footnotetext{
${ }^{21}$ The term 4(m) agreement comes from the corresponding section of the BHC Act.
} 
deficiencies at a firm. MOUs also differ from MRAs and MRIAs because MOUs are agreements between the Federal Reserve and the supervised firm, whereas MRAs and MRIAs are determined by the Federal Reserve alone. MOUs often incorporate restrictions on a firm during the period in which it is remediating the concerns raised in the MOU.

MRAs, MRIAs, 4Ms and MOUs are typically considered confidential supervisory information and thus are not publicly disclosed by the Federal Reserve. In contrast, most formal supervisory actions such as written agreements, cease and desist orders, and fines ("civil money penalties”) are publicly disclosed by the Federal Reserve Board. Written agreements and certain cease and desist orders (referred to as "consent orders") are agreed between the Federal Reserve and an institution, and stipulate certain findings about the firm and its actions and specify a course of correction to address the findings. Cease and desist orders can also be imposed without the agreement of the firm. 4M agreements may be issued when a holding company is either engaged in non-permissible activities, or when the holding company or one of its depository institution subsidiaries is either inadequately capitalized or not well managed. These formal supervisory actions have legal force, meaning that should the firm fail to meet the terms of the action, it can face fines and other actions, such as a requirement to restrict its growth or to divest certain assets.

The severity of the supervisory action taken depends on the severity of the deficiency that has been identified. It is not necessary to start with less severe actions before imposing more severe ones or for supervisors to take informal enforcement actions before taking formal ones, though escalation of insufficiently addressed actions certainly does occur. MRAs, MRIAs and both formal and informal enforcement actions can be initiated by the firm-focused supervisory team; they can also be initiated by other supervisory staff in FISG or at the Board of Governors in coordination with the firm-focused team, for instance, as part of broad programs such as the CCAR and CLAR. Depending on their severity, MRAs and MRIAs given to firms in the LISCC portfolio can be reviewed by and subject to the approval of the SSO's management or the LISCC Operating Committee. MOUs and formal enforcement actions are developed jointly by FRBNY and Board of Governors staff, and are signed by officials of the Reserve Bank and/or of the Board of Governors.

Supervisory actions typically are in force for a year or more as the management of the firm adopts changes to address issues raised in the actions. Table 2 shows the duration of 
supervisory actions at Second District LISCC institutions issued between 2011 and 2014 that were closed or still ongoing as of December 2014.

\title{
Table 2: Duration (years) of supervisory action issued to LISCC Institutions in the Second Federal Reserve District, Jan2011 - Nov2014
}

\author{
Issues Closed (resolved) as of November 2014
}

\begin{tabular}{lrrrr}
\hline Issue Type & Average & Min & Max & Count \\
\hline Matter Requiring Attention (MRA) & 1.4 & 0.0 & 3.5 & 680 \\
Matter Requiring Immediate Attention (MRIA) & 1.0 & 0.0 & 2.7 & 110 \\
Formal Action & 0.5 & 0.0 & 1.5 & 10 \\
\hline \multicolumn{1}{c}{ Issues Open (ongoing) as of November 2014 } & & & & \\
\hline & Average & Min & Max & Count \\
Issue Type & & & & \\
\hline Matter Requiring Attention (MRA) & 1.7 & 0.1 & 3.9 & 660 \\
Matter Requiring Immediate Attention (MRIA) & 1.8 & 0.2 & 3.8 & 50 \\
Formal Action & 2.7 & 0.9 & 4.0 & 10 \\
Memorandum of Understanding (MOU) and 4M & 2.3 & 0.1 & 3.2 & 20 \\
\hline
\end{tabular}

Notes: All counts are rounded to the nearest ten. This table shows summary statistics for the duration of supervisory actions. The table includes supervisory actions issued to LISCC financial institutions supervised by FRBNY between January 2011 and November 2014 and therefore the maximum duration is about 4 years. Source: FRBNY internal data on enforcement activity.

Tracking progress against supervisory actions, especially MRAs and MRIAs, is one of the key elements of continuous monitoring. Typically, the corporate function specialists on the team are administratively responsible for this tracking, with assessment of the steps taken by the firm to address the issues identified in the action being done by subject matter experts, such as other team members or staff from the risk departments. A variety of inputs can help determine whether an action can be lifted, including independent review and testing done by the supervisory team and the work of the firm's internal audit team (which would typically be the group within the firm responsible for tracking and determining compliance with enforcement actions). A key question in determining whether the action can be closed is whether the changes implemented by the firm to address the concerns in the enforcement action are sustainable over time. Depending on the severity of the deficiency addressed in the action, the decision about whether the issues have been addressed could rest with the supervisory team and SSO or could 
require vetting and approval by the LISCC Operating Committee (for firms in the LISCC portfolio) or by more senior officials at the Reserve Bank or Board of Governors.

\section{IV.F BHC Ratings}

In addition to enforcement actions, supervisory ratings are a critical product of the informationgathering and analysis done by the team over the course of the year. Bank holding companies are assigned a 1-to-5 rating under the "RFI/C(D)" rating system. The letters indicate different components considered in the rating - " $R$ " is for risk management, " $F$ " is for financial condition, "I" is for potential impact of the non-depository entities in the holding company on the depository institution(s) in the holding company, "C" is for the composite rating (that is, the overall rating considering and weighing the ratings on "R", " $F$ " and "I"), and " $D$ " is the rating assigned to the depositories (e.g., commercial banks or thrifts) owned by the holding company. The " $\mathrm{R}$ " and " $F$ " ratings have sub-components capturing different aspects of risk management (e.g., board and senior management oversight; policies, procedures, and limits) and financial condition (e.g., capital, liquidity, asset quality, and earnings), each of which is assigned its own rating. The " $R$ " and " $F$ " ratings are a summary of these sub-components (though generally not a simple average) and the composite "C" rating reflects the ratings of the individual " $\mathrm{R}$ ", " $\mathrm{F}$ ” and "I” components (though, again, generally not a simple average). The highest rating is a " 1 ” (indicating the strongest performance and practices and least amount of supervisory concern), while a rating of " 5 ” indicates the lowest performance and a very high degree of supervisory concern (Board of Governors of the Federal Reserve System 2004). Ratings are assigned on an absolute basis rather than a relative one, so the median rating across firms can change over time and based on economic and financial market conditions. In addition, some studies have found differences in supervisory stringency in assigning ratings over the business cycle (Krainer and Lopez 2009).

Ratings are important supervisory outputs because they help communicate supervisors' views of the firm to its management and board of directors (typically, information about a BHC's $\mathrm{RFI} / \mathrm{C}(\mathrm{D})$ rating is closely held within the firm), because they foster communication and common understanding about relative and absolute assessments of different BHCs within the Federal Reserve, and because BHCs with low ratings can face restrictions on their activities and growth, for example, through merger and branching approvals. For these and perhaps for other 
reasons, BHC management and boards of directors have incentives to ensure that their firms have good supervisory ratings.

While ratings can be changed at any point during the year based on new information or analysis, in general, ratings for the large, complex firms in the LISCC portfolio are assigned once a year. The process of assigning ratings is referred to as "roll up," reflecting the idea that the rating incorporates all the information and analysis generated by the firm-focused supervisory team and other supervisory staff over the course of the year. For the large, complex banking firms, the roll up begins with the SSO and supervisory team proposing ratings for the components and composite. The team documents the rationale for the ratings based on assessments made over the course of the year via continuous monitoring, enhanced continuous monitoring and examinations; input from supervisory programs such as the CCAR and CLAR (which are critical in determining the capital and liquidity sub-components, respectively, of the "F" rating and the risk management elements of the " $\mathrm{R}$ " rating); peer comparisons; and other data and analysis. Ratings changes receive particular attention. The proposals developed by the supervisory team are reviewed by others in FISG, then by the LISCC Operating Committee, which has final approval of the rating. Typically, these rating vettings are performed all firms in the LISCC portfolio at the same time, as a way of promoting consistency across firms and across Federal Reserve Districts.

\section{IV.G Planning and Priorities}

While the work of the firm-focused supervisory teams is on-going over the year, it is based on an annual cycle of planning and evaluation. The cycle begins with an assessment by the teams of the key risks facing each firm based on the firm's business line focus, strategies, and financial condition. Identifying these risks helps focus the work of the supervisory team by ensuring that the most important risks are addressed in the work plan for the year.

The key output of this process is the "supervision plan," which outlines what the firmfocused team plans to do over the coming year, including continuous monitoring, enhanced continuous monitoring, examinations, and work on horizontal programs such as CCAR, CLAR, and the SRP. The supervision plan is developed by the SSO based on guidance provided by the relevant System oversight group for firms in the LBO and FBO portfolios and by the LISCC Operating Committee for firms in the LISCC portfolio; the LISCC Operating Committee sets 
final priorities for supervisory plans for firms in the LISCC portfolio. The guidance helps establish priorities among various cross-firm projects and programs, such as the CCAR, and firm-specific work. For firms in the LISCC portfolio, these plans are discussed with the LISCC Operating Committee twice a year to reconfirm priorities and to establish new areas of focus based on industrywide or firm-specific developments. The supervisory plan is not shared with the supervised firm.

The goals of the planning process are to identify the key supervisory objectives for the coming year - for example, what areas or topics will the team analyze in depth or what topics will be the key focus of continuous monitoring and enhanced continuous monitoring - and to ensure that there are sufficient resources to achieve those objectives. Resources are often constrained in the sense that there is often more work that could be done than there is time or staff to do it. There is also a desire to leave space in the supervision plan to deal with for unforeseen developments so that these do not crowd out other important work.

Given the constraints on resources, priorities are set based on input from several sources, including the firm-focused supervisory team, the risk departments, other areas of FISG, and the relevant management oversight group. The LISCC Operating Committee, for instance, has subcommittees that review and suggest priorities in coordination with the risk departments and with analysts assessing capital and performance. These subcommittees bring together combinations of risk specialists, SSOs, other team members and analysts from FRBNY and from other Districts to share information and identify cross-firm issues (Board of Governors of the Federal Reserve System 2015c). This process results in suggestions for more in-depth work via enhanced continuous monitoring or horizontal examinations. Members of the FISG risk departments and business line specialists are actively involved in these sub-committees and so have a role in proposing these cross-firm projects.

Firm-specific work is generally proposed by the SSO and firm-focused supervisory team. The risk specialists, in coordination with the risk departments, may also suggest potential areas for further analysis at individual firms. Overall, about half the work done by the firm-focused teams (including the risk specialists) is firm-specific and about half involves cross-firm work, including System-wide programs such as CCAR and CLAR. 


\section{References}

Board of Governors of the Federal Reserve System. 2004. "Bank Holding Company Rating System.” SR 04-18. December 6, 2004. http://www.federalreserve.gov/boarddocs/srletters/2004/sr0418.htm

. 2005. "The Federal Reserve System: Purposes and Functions.” June 2005. http://www.federalreserve.gov/pf/pf.htm

. 2008. "Consolidated Supervision of Bank Holding Companies and the Combined U.S. Operation s of Foreign Banking Organizations." Attachement B.1. October 16, 2008. http://www.federalreserve.gov/boarddocs/srletters/2008/SR0809.htm

. 2010. "Banking Supervision and Regulation: Annual Report 2010.” http://www.federalreserve.gov/publications/annual-report/2010-banking-supervisionregulation.htm

—. 2012. "Consolidated Supervision Framework for Large Financial Institutions.” C SR 12-17. December 17, 2012. http://www.federalreserve.gov/bankinforeg/srletters/sr1217.htm

. 2013. "Supervisory Considerations http://www.federalreserve.gov/bankinforeg/srletters/sr1313.htm

. 2015a. "Bank Holding Company Supervision Manual.” Division of Banking Supervision and Regulation. January 2015. http://www.federalreserve.gov/boarddocs/supmanual/bhc/bhc.pdf

- 2015b. "Dodd-Frank Act Stress Test 2015: Supervisory Stress Test Methodology and Results. 2015. http://www.federalreserve.gov/newsevents/press/bcreg/bcreg20150305a1.pdf

. 2015c. "Governance Structure of the Large Institution Supervision Coordinating Committee (LISCC) Supervisory Program.” April 17, 2015. http://www.federalreserve.gov/bankinforeg/srletters/sr1507.htm

Dahlgren, Sarah J. 2011. “A New Era of Bank Supervision.” Remarks at the New York Bankers Association Financial Services Forum. New York, NY. November 11, 2011. http://www.newyorkfed.org/newsevents/speeches/2011/dahlgren111111.html 
Dudley, William C. 2014. "Improving Financial Institution Supervision - Examining and Addressing Regulatory Capture.” Testimony before the Senate Committee on Banking, Housing, and Urban Affairs, Financial Institutions and Consumer Protection Subcommittee, Washington DC. November 21, 2014. http://www.newyorkfed.org/newsevents/speeches/2014/dud141121.html

Federalreserve.gov. 2015a. "Large Institutions Supervision Coordinating Committee.” Accessed February 20, 2015. http://www.federalreserve.gov/bankinforeg/large-institutionsupervision.htm

. 2015b. "Reporting Forms: FR2052a." Accessed April 30. 2015. http://www.federalreserve.gov/apps/reportforms/reportdetail.aspx?sOoYJ+5BzDbpqbklR e3/1zdGfyNn/SeV

. 2015c. "Shared National Credit Program." Accessed April 30, 2015. http://www.federalreserve.gov/bankinforeg/snc.htm

2015d. “Supervision Manuals.” Accessed March 11, 2015. http://www.federalreserve.gov/boarddocs/supmanual/

. 2015e. "Supervision and Regulation Letters.” Accessed March 11, 2015. http://www.federalreserve.gov/bankinforeg/srletters/srletters.htm

Krainer, John and Jose A. Lopez. 2009. "Do Supervisory Rating Standards Change over Time?” Federal Reserve Bank of San Francisco Economic Review, 13-24.

Masciandaro, Donato, and Marc Quintyn. "8. The Evolution of Financial Supervision: The Continuing Search for the Holy Grail." SUERF 50th Anniversary Volume Chapters (2013): 263-318.

Mishkin, Frederic S. 2001. "Prudential Supervision: Why Is It Important and What Are the Issues?” In Prudential Supervision: What Works and What Doesn't, 1-30. University of Chicago Press.

Newyorkfed.org. 2014. “Financial Institution Supervision Group.” Accessed October 1, 2014. http://www.newyorkfed.org/financial-institution-supervision/financial-institutionsupervision-group.html

Tarullo, Daniel K., 2014. "Liquidity Regulation.” Speech at the 2014 Clearing House Annual Conference. New York, NY. November 20, 2014. http://www.federalreserve.gov/newsevents/speech/tarullo20141120a\%20.htm

Yellen, Janet L. 2015. "Improving the Oversight of Large Financial Institutions." Speech at the Citizen Budget Commission. New York, NY. March 3, 2015. http://www.federalreserve.gov/newsevents/speech/yellen20150303a.htm 